\title{
Vida na Corda Bamba
}

\section{Renata Couto de Azevedo de Oliveira}

Colagem é uma técnica artística de criação que consiste na junção de diversos elementos e formas com o objetivo de criar algo totalmente novo. Fiquei extremamente feliz e honrada ao ser convidada pelo Editor da Revista Eletrônica de Ciência Administrativa, Professor Luciano Rossoni, para criar uma imagem para a edição especial sobre literatura e organizações. Comecei a fazer colagens analógicas há mais ou menos 11 anos em um pequeno caderno. $\mathrm{O}$ experimento durou pouco e ficou de lado até o ano passado, quando a vontade de criar em meio ao caos pandêmico ressurgiu. O caderno foi preenchido com desenhos e as colagens ganharam novo formato, ocupando folhas maiores, páginas de jornal e até bulas do remédio. Do papel para o computador, do analógico para o digital, as colagens se multiplicaram. Justapor elementos que aparentemente não combinam, vazar imagens destacando a ausência, contar histórias sobre o que é normalizado e excluído. Colagem e literatura organizam elementos e emoções, e o resultado é um texto (no sentido semiótico), com estrutura e conteúdo próprios e especiais.

A imagem criada para essa edição é uma colagem digital que mostra uma pequena equilibrista andando numa corda na qual estão penduradas imagens que remetem aos exemplares literários usados nos artigos da chamada "Verso, prosa, drama e ficção: literatura e organizações". A inspiração veio da literatura de cordel, gênero que combina literatura e arte e cujos livretos são normalmente presos a uma corda com pregadores. As chaminés entre as quais a corda se estende são da usina termoelétrica de Battersea, em Londres (Reino Unido), hoje desativada. A imagem da usina tem valor sentimental e faz parte da cultura popular. É ela que aparece na capa do álbum "Animals", da banda inglesa Pink Floyd. Na capa, um porco flutua entre as torres da usina e foi originalmente concebida pelo guitarrista da banda, Roger Waters, o qual remete ao clássico literário "A Revolução dos Bichos", do também inglês George Orwell. Tanto o álbum quanto o livro tecem críticas aos sistemas políticos e às condições sociais em diferentes momentos da história.

Talvez a corda na colagem seja a metáfora para o mundo de experiências multifacetadas representadas na literatura, experiências através das quais as pessoas se organizam e tecem sua existência. Ela está entre as chaminés de uma forma organizacional, possivelmente sinalizando que a organização não é um ente estéril e separado da vida fora de seus muros. Nas páginas de jornais sindicais, clássicos da literatura brasileira, obras quase esquecidas e escritos populares encontramos debates que informam "inúmeros discursos pertinentes nos estudos organizacionais" (Ipiranga \& Saraiva, 2020, p.1). E tal qual como a equilibrista, todos nós andamos nessa corda e somos sustentados por ela.
Recebido em: 27/07/2021 Colagem convidada.

Check for updates

Renata Couto de Azevedo de Oliveira (iD),

Pesquisadora Independente, Brasil Doutora em Administração, Universidade do Grande Rio, Brasil

renatacouto@yahoo.com 


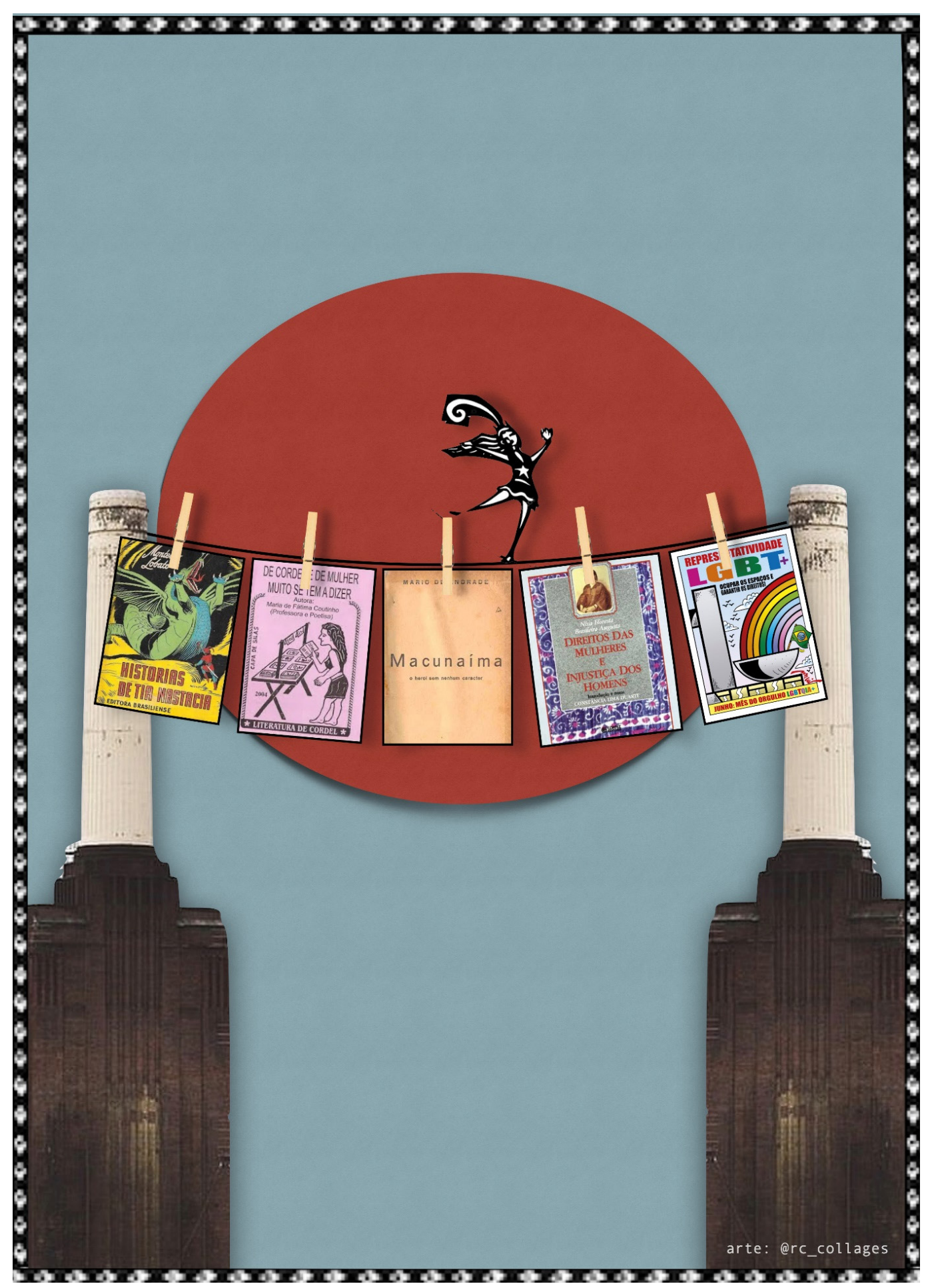

Figura 1. Vida em Corda Bamba.

\section{Referências}

Ipiranga, A. S. R. \& Saraiva, L. A. S. RECADM Chamada Especial: Verso, Prosa, Drama e Ficção: Literatura e Organizações. Revista Eletrônica de Ciência Administrativa. DOI: http://doi.org/10.5281/zenodo.3749372 